\title{
Fyn Kinase Modulates Synaptotoxicity, But Not Aberrant Sprouting, in Human Amyloid Precursor Protein Transgenic Mice
}

\author{
Jeannie Chin, ${ }^{1}$ Jorge J. Palop, ${ }^{1}$ Gui-Qiu Yu, ${ }^{1}$ Nobuhiko Kojima, ${ }^{2}$ Eliezer Masliah, ${ }^{3}$ and Lennart Mucke ${ }^{1}$ \\ ${ }^{1}$ Gladstone Institute of Neurological Disease and Department of Neurology, University of California, San Francisco, California 94141, ${ }^{2}$ Neuronal Circuit \\ Mechanisms Research Group, RIKEN Brain Science Institute, Wako 351-0198, Japan, and 32Departments of Neurosciences and Pathology, University of \\ California at San Diego, La Jolla, California 92093
}

\begin{abstract}
Alzheimer's disease (AD), the most common neurodegenerative disorder, results in progressive degeneration of synapses and aberrant sprouting of axon terminals. The mechanisms underlying these seemingly opposing cellular phenomena are unclear. We hypothesized that Fyn kinase may play a role in one or both of these processes because it is increased in AD brains and because it is involved in synaptic plasticity and axonal outgrowth. We investigated the effects of Fyn on AD-related synaptotoxicity and aberrant axonal sprouting by ablating or overexpressing Fyn in human amyloid precursor protein (hAPP) transgenic mice.

On the $\mathrm{fyn}^{+/+}$background, hAPP/amyloid $\beta$ peptide $(\mathrm{A} \beta)$ decreased hippocampal levels of synaptophysin-immunoreactive presynaptic terminals (SIPTs), consistent with previous findings. On the $f y n^{-1-}$ background, hAPP/A $\beta$ did not affect SIPTs. SIPT reductions correlated with hippocampal A $\beta$ levels in hAPP/fyn ${ }^{+/+}$, but not hAPP/fyn ${ }^{-/-}$, mice suggesting that Fyn provides a critical link between hAPP/A $\beta$ and SIPTs. Furthermore, overexpression of Fyn exacerbated SIPT reductions in hAPP mice. We also found that the susceptibility of mice to hAPP/A $\beta$-induced premature mortality was decreased by Fyn ablation and increased by Fyn overexpression. In contrast, axonal sprouting in the hippocampus of hAPP mice was unaffected. We conclude that Fyn-dependent pathways are critical in AD-related synaptotoxicity and that the pathogenesis of hAPP/A $\beta$-induced neuronal alterations may be mechanistically heterogenous.
\end{abstract}

Key words: Alzheimer's disease; amyloid $\beta$; Fyn kinase; synaptic deficits; signaling; sprouting; GAP-43; neurodegeneration

\section{Introduction}

The amyloid precursor protein (APP) is expressed in many cell types and is particularly abundant in synapses. One of its metabolites, amyloid $\beta$ peptide $(\mathrm{A} \beta)$, suppresses synaptic transmission and may participate in the regulation of neuronal activity (Hsia et al., 1999; Kamenetz et al., 2003). Mutations in the human APP (hAPP) gene that lead to increased levels of $A \beta$ cause autosomal dominant familial Alzheimer's disease (FAD) (Selkoe and Schenk, 2003). Of several species of $A \beta$ produced, the 42 -residue form (A $\beta 1-42)$ is particularly susceptible to aggregation and is a primary constituent of neuritic amyloid plaques, pathological hallmarks of the disease (Selkoe and Schenk, 2003). Both FAD and sporadic $\mathrm{AD}$ are associated with a progressive degeneration of neurons and synapses (DeKosky and Scheff, 1990; Terry et al., 1999) and an aberrant sprouting of axon terminals (Geddes et al., 1985; Masliah et al., 1991; Arendt, 2001). The precise relationship

Received Jan. 23, 2004; revised April 8, 2004; accepted April 9, 2004.

This work was supported by National Institutes of Health Grants NS41787 and AG022074 (L.M.), the John Douglas French Alzheimer's Foundation (J.C.), C. Lester and Audrey Hogan (J.J.P.), and the Hillblom Center for the Biology of Aging (J.J.P). We thank Gary Howard and Stephen Ordway for editorial review of this manuscript and Denise McPherson for administrative assistance.

Correspondence should be addressed to Dr. Lennart Mucke, Gladstone Institute of Neurological Disease, P.0. Box 419100, San Francisco, CA 94141-9100. E-mail: Imucke@gladstone.ucsf.edu.

DOI:10.1523/JNEUROSCI.0277-04.2004

Copyright $\odot 2004$ Society for Neuroscience $\quad$ 0270-6474/04/244692-06\$15.00/0 between hAPP, $A \beta$, plaques, synaptic loss, axonal sprouting, and cognitive decline in $\mathrm{AD}$ is unknown.

Although amyloid plaques are a diagnostic feature of $\mathrm{AD}$, growing evidence suggests that plaques may not be the primary cause of AD-related synaptic alterations and cognitive decline. In transgenic (TG) mice overexpressing $\mathrm{hAPP} / \mathrm{A} \beta$ in neurons, synaptic and behavioral deficits are detectable well before plaque formation (Holcomb et al., 1999; Hsia et al., 1999; Mucke et al., 2000; Raber et al., 2000; Buttini et al., 2002; Westerman et al., 2002; Palop et al., 2003). A $\beta 1-42$ can form small neurotoxic assemblies that act intracellularly or extracellularly and could impair neuronal and synaptic functions independent of plaques (Lambert et al., 1998; Caughey and Lansbury, 2003). A $\beta$ interacts with a number of cell surface receptors on neurons, including integrins (Sabo et al., 1995; Bi et al., 2002), $\alpha 7$ nicotinic ACh receptors (Dineley et al., 2001), and the p75 neurotrophin receptor (Yaar et al., 1997). Additionally, several intracellular molecules have been implicated in $\mathrm{A} \beta$-induced alterations of signaling cascades that could result in the dysfunction or degeneration of neurons (Klein, 2000; Small et al., 2001; Williamson et al., 2002; Grace and Busciglio, 2003).

One of these intracellular molecules is Fyn kinase, a member of the src family of nonreceptor tyrosine kinases. Fyn immunoreactivity (IR) is increased in AD brains (Shirazi and Wood, 1993), and genetic ablation of Fyn rendered hippocampal slices resistant to the neurotoxic effects of $A \beta$ oligomers (Lambert et al., 
1998). Here, we used genetic modulations of Fyn (overexpression vs ablation) to test the hypotheses that Fyn is involved in degenerative (synaptic deficits) and trophic (aberrant sprouting) effects of hAPP/A $\beta$.

\section{Materials and Methods}

TG mice. hAPP ${ }_{\mathrm{FAD}}$ TG lines J20 and J9 produce hAPP carrying Swedish (K670N, M671L) and Indiana (V717F) FAD mutations (hAPP770 numbering) (Rockenstein et al., 1995; Mucke et al., 2000). Lines were crossed for 6-10 generations onto a C57BL/6 background using mice from The Jackson Laboratory (Bar Harbor, ME). Heterozygous FYN TG mice (line N8) overexpress wild-type mouse Fyn directed by the calcium/calmodulindependent protein kinase II $\alpha$ promoter on a C57BL/6 background (Kojima et al., 1997, 1998). $\mathrm{Fyn}^{-1-}$ mice (Grant et al., 1992) on a 129/SVJ background were obtained from The Jackson Laboratory. Measurements were performed on gender-balanced groups. Mice were anesthetized and flushperfused transcardially with PBS. Hemibrains were fixed in $4 \%$ phosphatebuffered paraformaldehyde or stored at $-70^{\circ} \mathrm{C}$.

Growth-associated protein 43 analysis. Vibratome $(50 \mu \mathrm{m})$ or sliding microtome $(30 \mu \mathrm{m})$ sections were avidin-biotin/immunoperoxidase stained using anti-growth-associated protein 43 (GAP-43) (1:400; Sigma, St. Louis, MO), biotinylated donkey anti-mouse (1:500; Jackson ImmunoResearch, West Grove, PA), and DAB. For quantitation of GAP-43 IR, two sections per mouse were used. In each section, the integrated optical density of staining in two areas of the outer molecular layer (OML) and two areas of the middle molecular layer (MML) of the dentate gyrus was determined by BioQuant Image Analysis (R\&M Biometrics, Nashville, TN). Measurements for each area were averaged and used to calculate group means.

Synaptophysin-immunoreactive presynaptic terminal analysis. Vibratome sections $(50 \mu \mathrm{m})$ were labeled with anti-synaptophysin $(1 \mu \mathrm{g} /$ $\mathrm{ml}$; Boehringer Mannheim, Indianapolis, IN) and FITC-conjugated horse anti-mouse $\operatorname{IgG}(1: 75$; Vector Laboratories, Burlingame, CA) and imaged by confocal microscopy (MRC1024; Bio-Rad, Hercules, CA). For each experiment, we first determined the linear range of the fluorescence intensity of synaptophysin-immunoreactive presynaptic terminals (SIPTs) in control sections from nontransgenic (NTG) wild-type mice. This setting was then used to collect all images analyzed in the same experiment. Sections were blind coded and processed in parallel. Twelve confocal images of the molecular layer of the dentate gyrus were obtained from three sections per mouse and analyzed with NIH Image software. The area occupied by SIPTs of defined signal intensity was quantified and expressed as a percentage of the total image area, as described (Masliah et al., 1992; Buttini et al., 1999). Previous studies indicated that SIPT measurements are not significantly influenced by genetic backgrounds (Mucke et al., 1994).

$A \beta$ ELISAs. Snap-frozen hippocampi were homogenized in guanidine buffer, and $\mathrm{A} \beta$ peptides were quantitated by ELISA, as described (Johnson-Wood et al., 1997).

Plaque quantitation. Vibratome sections were immunoperoxidase labeled with an Elite kit (Vector Laboratories), using biotinylated antiA $\beta 1-5$ (5 $\mu \mathrm{g} / \mathrm{ml}$, 3D6; Elan Pharmaceuticals, South San Francisco, CA) (Johnson-Wood et al., 1997) and DAB, and counterstained with $1 \%$ hematoxylin. The percentage of area of the hippocampus covered by 3D6 IR was determined with a Quantimet 570C (Leica, Deerfield, IL). Three sections were analyzed per mouse, and the average was used to calculate group means.

Statistical analyses. Statistical analyses were performed with Statview 5.0 (SAS Institute, Cary, NC). Differences between means were assessed by Student's $t$ test or two-factor ANOVA, followed by the Tukey-Kramer post hoc test. Correlations were assessed by simple regression analysis.

\section{Results}

Modulating Fyn levels alters $\mathrm{hAPP} \mathrm{FAD}_{\mathrm{FA}} / \mathrm{A} \beta$-induced synaptotoxicity We examined SIPT levels in $\mathrm{hAPP}_{\mathrm{FAD}}$ mice in the context of wild-type, increased, or absent expression of Fyn. First, we crossed heterozygous FYN TG mice in which wild-type mouse Fyn is overexpressed in the forebrain (Kojima et al., 1997, 1998) with heterozygous TG mice from the low $\mathrm{hAPP}$ FAD $/ \mathrm{A} \beta$ expresser line J9 (Hsia et al., 1999; Mucke et al., 2000), resulting in $\mathrm{fyn}^{+/+}$ littermates of four genotypes: $\mathrm{hAPP}_{\text {low }} / \mathrm{FYN}, \mathrm{hAPP}_{\text {low }}, \mathrm{FYN}$, and NTG.

Overexpression of Fyn worsened SIPT reductions in $\mathrm{hAPP}_{\text {low }}$ mice (Fig. $1 A)$. Both hAPP low $_{(}(p<0.0001)$ and FYN $(p<0.001)$ had a clear effect on SIPT levels. Post hoc analysis revealed that SIPT levels were significantly lower in doubly TG hAPP low $/ \mathrm{FYN}$ mice than in singly TG hAPP low $(p<0.05)$ or FYN $(p<0.001)$ mice (Fig. $1 B$ ). Although the hAPP low -induced SIPT reductions were relatively modest, we have previously shown that such SIPT reductions are accompanied by major reductions in synaptic transmission strength, which underscores their pathophysiological significance (Hsia et al., 1999).

Next, we crossed Fyn-deficient ( $f y n^{-/-}$) mice (Grant et al., 1992) for two generations with heterozygous TG mice from the high hAPP ${ }_{\mathrm{FAD}} / \mathrm{A} \beta$ expresser line J20 (Mucke et al., 2000; Palop et al., 2003), yielding hAPP high $_{\text {h }} / f n^{+/+}, \mathrm{hAPP}_{\text {high }} / f y n^{-1}-, f y n^{+1+}$, and $f y n^{-1-}$ mice. Although ablation of Fyn per se decreased SIPT levels compared with $f y n^{+/+}$littermates (Fig. $1 C$ ), there was a significant interaction between the $\mathrm{hAPP}_{\text {high }}$ and fyn genotype $(p<0.0001)$, indicating that hAPP $\mathrm{high}_{\text {hifferentially affects pre- }}$ synaptic terminals in the presence or absence of wild-type Fyn. Indeed, overexpression of $\mathrm{hAPP}_{\text {high }}$ significantly reduced SIPT levels in $f y n^{+/+}$, but not $f y n^{-/-}$, mice (Fig. 1C).

\section{Modulating Fyn levels does not alter A $\beta$ levels but changes the relationship between $A \beta$ and SIPT}

To determine whether the genetic modulation of Fyn affects the production or metabolism of $\mathrm{A} \beta$, we examined hippocampal $\mathrm{A} \beta$ levels by ELISA. The levels of $A \beta 1-42$ and $A \beta 1-x$ (approximates total $A \beta$ ), and $A \beta 1-42 / A \beta 1-x$ ratios, were comparable in 6to 8 -month-old doubly TG $\mathrm{hAPP}_{\text {low }} / \mathrm{FYN}$ mice and singly TG $\mathrm{hAPP}_{\text {low }}$ mice (Fig. $1 D$ ), suggesting that increased levels of Fyn do not alter the production or degradation of $\mathrm{A} \beta$.

$\mathrm{A} \beta$ levels in 4- to 5-month-old hAPP ${ }_{\text {high }}$ mice were also comparable on the $f y n^{+/+}$and $f y n^{-1-}$ backgrounds (Fig. $1 E$ ). Interestingly, SIPT levels at this age correlated inversely with $\mathrm{A} \beta 1-42$ levels and $\mathrm{A} \beta 1-42 / \mathrm{A} \beta 1-\mathrm{x}$ ratios in $\mathrm{hAPP}_{\text {high }} /$ fyn $^{+/+}$mice but not in hAPP ${ }_{\text {high }} / f y n^{-/-}$mice (Fig. $1 E$ ), suggesting that Fyn is critical in linking $\mathrm{A} \beta$ with SIPT reductions.

At 4-5 months, hAPP ${ }_{\text {high }}$ mice had no or only few plaques on the $f y n^{+/+}$or $f y n^{-/-}$backgrounds (data not shown). We therefore compared plaque loads in $\mathrm{hAPP}_{\text {high }}$ mice at 8-10 months of age, when all of them had plaques. Their hippocampal plaque loads were comparable on the $f y n^{+/+}$and $f y n^{-1-}$ backgrounds (Fig. $1 G$ ), suggesting that the differential effects of hAPP $\mathrm{FAD}_{\mathrm{FA}} / \mathrm{A} \beta$ on these backgrounds were not attributable to modulation of $\mathrm{A} \beta$ deposition.

\section{Premature death in hAPP ${ }_{\mathrm{FAD}}$ mice is modulated by Fyn}

Some lines of hAPP mice exhibit premature mortality (Hsiao et al., 1995; Carlson et al., 1997), but the mechanisms remain unknown. Approximately $10 \%$ of our $\mathrm{hAPP}_{\text {high }} /$ fyn $^{+/+}$mice died before 6 months of age (Fig. $1 H$ ), compared with $0 \%$ of NTG $f y n^{+1+}$ controls. Although fyn $n^{-1-}$ mice were slightly more susceptible to premature death than $f y n^{+/+}$mice, ablation of Fyn improved survival in $\mathrm{hAPP}_{\text {high }}$ mice, and $\mathrm{hAPP}_{\text {high }}$ did not increase premature mortality on the $f y n^{-1-}$ background (Fig. $1 H$ ). Notably, NTG and hAPP ${ }_{\text {low }}$ or FYN singly TG mice did not die

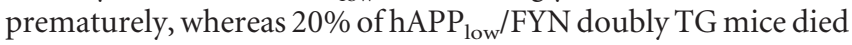
during the first 6 months after birth (Fig. 1I). 


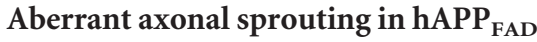
mice depends on levels of hAPP ${ }_{\mathrm{FAD}} / \mathrm{A} \boldsymbol{\beta}$ expression

In $\mathrm{AD}$, the loss of presynaptic terminals is associated with aberrant axonal sprouting (Geddes et al., 1985; Masliah et al., 1991; Arendt, 2001). To determine whether these processes are linked mechanistically, we analyzed axonal sprouting in our TG models with antibodies against GAP-43, which is expressed by many types of growing axons (Benowitz and Perrone-Bizzozero, 1991). hAPP ${ }_{\text {high }}$ mice showed prominent age-dependent axonal sprouting in the molecular layer of the dentate gyrus (Fig. $2 A, B)$. This layer contains the dendritic arbors of the dentate granule cells and presynaptic terminals of afferent projections from other regions such as the entorhinal cortex (glutamatergic) and the basal forebrain and medial septum (cholinergic). At 4 months of age, hAPP ${ }_{\text {high }}$ mice showed aberrant sprouting primarily in the OML (Fig. 2 B). By 6 months, significant sprouting was observed in both the OML and the MML (Fig. $2 A, B, D$ ). In contrast, $\mathrm{hAPP}_{\text {low }}$ mice had no significant increase in axonal sprouting at 6 (Fig. 2C,E) or 20 (data not shown) months, suggesting that a threshold level of hAPP $\mathrm{FAD}_{\mathrm{F}} / \mathrm{A} \beta$ expression is required to elicit aberrant sprouting.

\section{Aberrant axonal sprouting in $\mathrm{hAPP}_{\mathrm{FAD}}$} mice is independent of Fyn kinase

Because genetic ablation of Fyn prevented additional SIPT reductions (Fig. 1C) and eliminated the inverse correlation between SIPT and $\mathrm{A} \beta$ levels in $\mathrm{hAPP}$ high mice (Fig. $1 F)$, we examined whether ablation of Fyn also interfered with aberrant sprouting. Ablation of Fyn did not alter either the magnitude of sprouting (Fig. $3 A$ ) or the age at which sprouting became evident (data not shown). In 4- to 5-month-old mice, GAP-43 in the OML was unaffected by the fyn genotype but was increased by $\mathrm{hAPP}_{\text {high }}$ on both $f y n^{+/+}$and $f y n^{-1-}$ backgrounds $(p<0.0001)$, and there was no GAP-43-related interaction between $\mathrm{hAPP}_{\text {high }}$ and $f y n$. The magnitude of axonal sprouting in $\mathrm{hAPP}_{\text {high }}$ mice did not correlate with hippocampal $\mathrm{A} \beta$ levels on $f y n^{+/+}$and $f y n^{-l-}$ backgrounds (Fig. $3 B$ ). Finally, overexpression of Fyn failed to elicit aberrant sprouting in $\mathrm{hAPP}_{\text {low }} / \mathrm{FYN}$ doubly TG mice (Fig. 3C).

\section{Discussion}

We have identified a mechanistic dichotomy in the cellular effects elicited by $\mathrm{hAPP} \mathrm{FAD}_{\mathrm{F}} / \mathrm{A} \beta$ in vivo. hAP$\mathrm{P}_{\mathrm{FAD}} / \mathrm{A} \beta$ induces both synaptotoxicity and aberrant growth processes. Our results suggest that only the former involves Fyn kinase-dependent signaling pathways.

\section{$\mathbf{F}$}
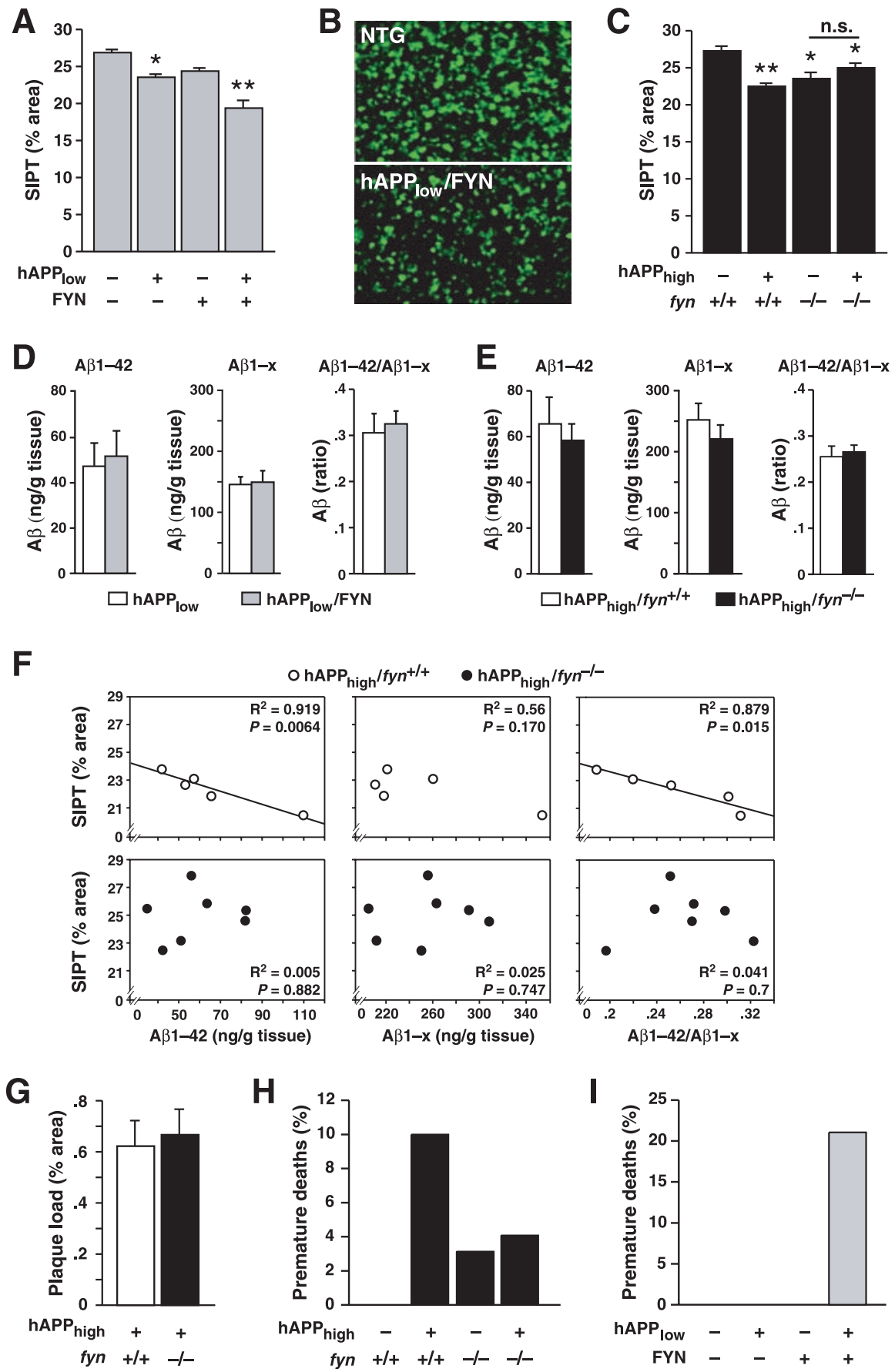

Figure 1. Genetic modulation of mouse Fyn alters the extent of $\mathrm{hAPP}_{\mathrm{FAD}} / \mathrm{A} \beta$-induced reductions in SIPT and premature mortality. FYN refers to the Fyn transgene, and fyn refers to the endogenous gene. n.S., Not significant. ${ }^{*} p=0.001 ;{ }^{* *} p<0.0005$ versus NTG wild-type littermate controls. $A$, Overexpressing Fyn exacerbated SIPT reductions in $\mathrm{hAPP}_{\text {low }}$ mice $(n=5-9$ mice/ genotype; age, 6-8 months). $B$, Confocal microscopic images illustrating SIPT in the OML of an NTG mouse (top) and an hAPP low $_{1}$ FYN doubly TG mouse (bottom). C, Ablating Fyn reduced SIPT levels but also prevented additional SIPT reductions in hAPP ${ }_{\text {high }}$ mice ( $n=5-8$ mice/genotype; age, 4-5 months). D, Overexpressing Fyn did not alter A $\beta$ levels in $\mathrm{hAPP}_{\text {low }}$ mice $(n=5-9$ mice/ genotype; age, $6-8$ months). $E$, Ablating Fyn did not alter $A \beta$ levels in $\mathrm{hAPP}_{\text {high }}$ mice $(n=5-8$ mice/genotype; age, $4-5$ months). F, SIPT levels correlated inversely with $A \beta 1-42$ levels and $A \beta 1-42 / A \beta 1-x$ ratios in $\mathrm{hAPP}_{\text {high }}$ mice on the fyn ${ }^{+/+}$, but not fyn ${ }^{-1-}$, background (age, 4-5 months). G, Comparable plaque load in hAPP $_{\text {high }}$ mice on fyn ${ }^{+1+}$ and fyn ${ }^{-1-}$ backgrounds ( $n=7-8$ mice/genotype; age, 8-10 months). $H, I$, Proportion of mice that died prematurely in each of the groups indicated during the first 6 months postnatally (percentage of $38-64$ mice/genotype). Husbandry conditions were similar for all groups.

A significant correlation between $\mathrm{A} \beta$ levels and SIPT levels was observed in $\mathrm{hAPP}_{\text {high }}$ mice on the $f y n^{+/+}$, but not $f y n^{-1-}$, background, suggesting that Fyn is necessary for hAPP $\mathrm{FAD}_{\mathrm{D}} / \mathrm{A} \beta$ to affect SIPT levels. One caveat is that SIPT levels were lower in 

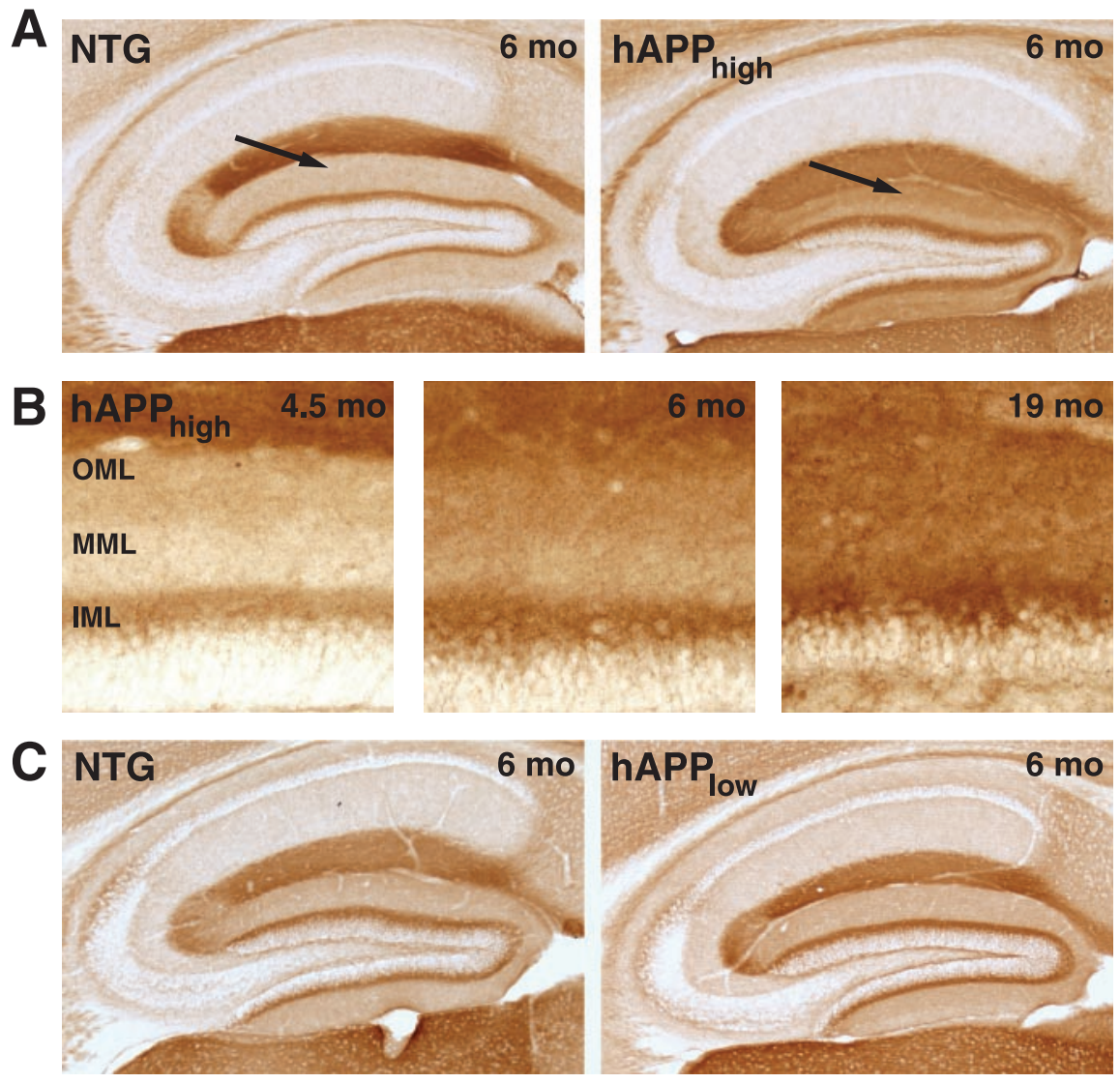

D
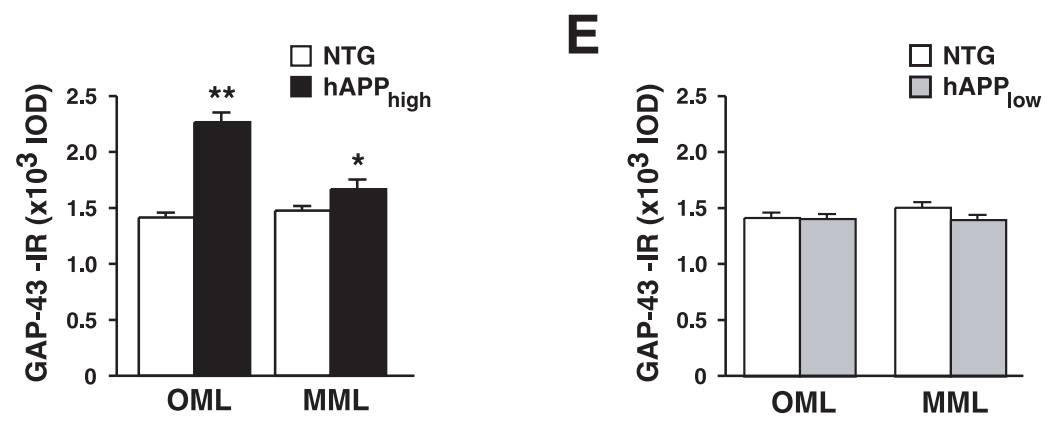

Figure 2. Aberrant axonal sprouting in $h A P P_{F A D}$ mice depends on age and $h A P P_{F A D}$ expression levels. $A$, Photomicrographs of GAP-43-IR in the hippocampus of a 6-month-old NTG mouse and an hAPP ${ }_{\text {high }}$ TG littermate. Prominent aberrant sprouting is evident in the molecular layer of the $\mathrm{hAPP}_{\text {high }}$ mouse (arrow). $B$, In hAPP ${ }_{\text {high }}$ mice, GAP-43-IR in this layer further increased with age. C, Photomicrographs showing normal GAP-43-IR in the hippocampus of a 6-month-old NTG mouse and an hAPP ${ }_{\text {low }}$ TG littermate. D, Quantitation of GAP-43-IR in 6-month-old hAPP ${ }_{\text {high }}$ mice revealed a $60 \%$ increase in the $0 \mathrm{ML}$ and a $13 \%$ increase in the MML ( $n=10-13$ mice/genotype). ${ }^{*} p<0.05$; ${ }^{* *} p<0.0001$ versus NTG wild-type littermates. $E$, Quantitation of GAP-43-IR in the $0 M L$ and $M M L$ revealed no aberrant sprouting in $\mathrm{hAPP}_{\text {low }}$ mice ( $n=11-13$ mice/genotype). mo, Months; IML, inner molecular layer.

$f y n^{-1-}$ mice than in $f y n^{+/+}$mice even in the absence of $\mathrm{hAPP}_{\mathrm{FAD}} / \mathrm{A} \beta$ expression, possibly relating to other hippocampal abnormalities (Grant et al., 1992; Kojima et al., 1997), which could create a "floor" effect in $f y n^{-1-}$ mice, preventing additional reductions by other insults. However, increased expression of Fyn exacerbated SIPT reductions in $\mathrm{hAPP}_{\text {low }}$ mice, providing additional direct evidence for a copathogenic role of Fyn in $\mathrm{hAPP}_{\mathrm{FAD}} / \mathrm{A} \beta$-induced synaptotoxicity.

Increased expression of Fyn by itself did not increase premature mortality in singly TG FYN mice, consistent with previous findings (Kojima et al., 1998). However, ablating Fyn decreased, whereas overexpressing Fyn increased premature mortality in
hAPP $_{\mathrm{FAD}}$ mice, suggesting that Fyn plays a key role in this disease manifestation. Because overexpression of Fyn was restricted to forebrain neurons (Kojima et al., 1998), our findings suggest a central mechanism. Although we did not witness seizures or the premature deaths during this study, we cannot exclude the involvement of epileptiform activities. hAPP mice on an FVB/N background were more prone to seizures and premature mortality than NTG littermates (Hsiao et al., 1995). Furthermore, Fyn phosphorylates the subunit $2 \mathrm{~B}$ of the NMDA receptor, and FYN TG mice showed accelerated kindling, which was retarded by NMDA receptor antagonists (Kojima et al., 1998). Thus, increased expression of Fyn may lower the seizure threshold in hAPP ${ }_{\mathrm{FAD}}$ mice.

In contrast to synaptotoxicity and premature mortality, axonal sprouting was not altered by genetic modulation of Fyn in $\mathrm{hAPP}_{\mathrm{FAD}}$ mice. Aberrant sprouting is prominent in AD (Geddes et al., 1985; Masliah et al., 1991; Arendt, 2001) and has also been demonstrated in other lines of hAPP $\mathrm{FAD}$ mice (Phinney et al., 1999; Bronfman et al., 2000; Jaffar et al., 2001). hAPP ${ }_{\text {high }}$ mice exhibited sprouting on both $f y n^{+/+}$and $f y n^{-1-}$ backgrounds, and the magnitude of sprouting increased with age. In contrast, no sprouting was observed in $\mathrm{hAPP}_{\text {low }}$ mice, even when Fyn was overexpressed. Thus, aberrant sprouting in hAPP ${ }_{\mathrm{FAD}}$ mice depends on $\mathrm{hAPP}_{\mathrm{FAD}} / \mathrm{A} \beta$ levels and age but not on Fyn.

It is possible that Fyn-dependent synaptotoxicity is caused by $\mathrm{A} \beta$, whereas Fynindependent aberrant sprouting is caused by an alternative effect of the FAD mutation, another APP metabolite, or the precursor molecule itself. Consistent with this interpretation, SIPT reductions correlated with $\mathrm{A} \beta$ levels on the $f y n^{+/+}$, but not $f y n^{-1-}$, background, and SIPT reductions were worsened by overexpression of Fyn, whereas axonal sprouting did not correlate with $\mathrm{A} \beta$ levels on either background and was not worsened by overexpression of Fyn.

Alternatively, synaptotoxicity, premature death, and aberrant sprouting may all be caused by $\mathrm{A} \beta$, but through mechanistically distinct pathways that do or do not involve Fyn. The lack of correlation between aberrant sprouting in the dentate gyrus and $\mathrm{A} \beta$ levels does not necessarily invalidate this interpretation because the sprouting stimulus could act on neurons in other regions that project to the molecular layer of the dentate gyrus. In that case, sprouting might correlate with $\mathrm{A} \beta$ levels in regions containing the cell bodies of the projections, a possibility that remains to be tested.

Although additional research is needed to define the precise interactions between $A \beta$ and Fyn-related signaling pathways, there is evidence that integrins, cadherins, $N$-syndecan, FAK, paxillin, and tau-phosphorylating kinases might be involved 
A

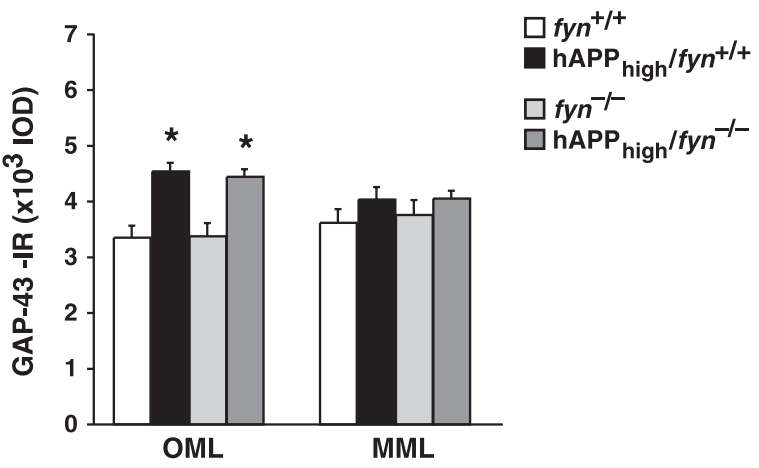

B
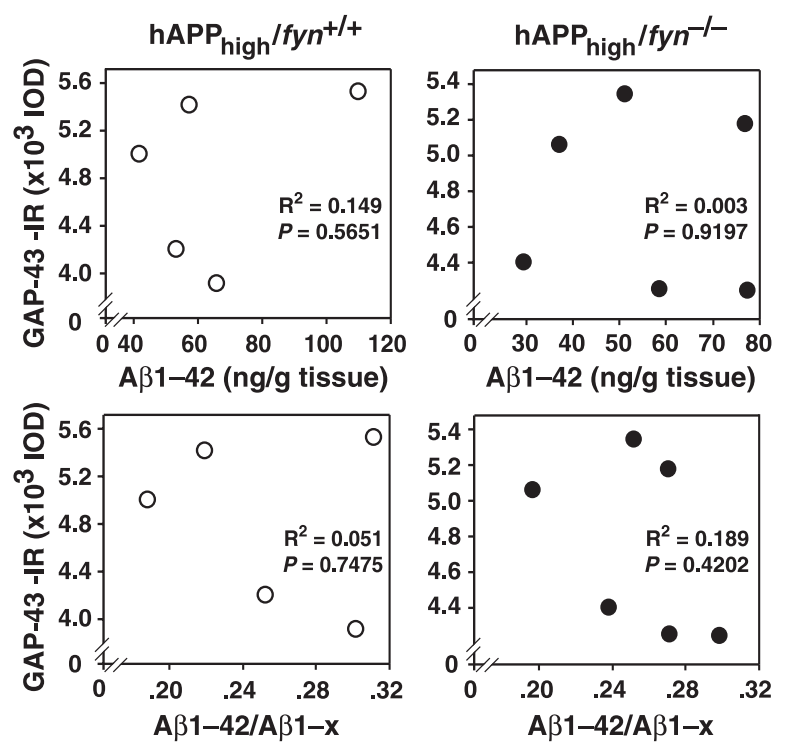

C

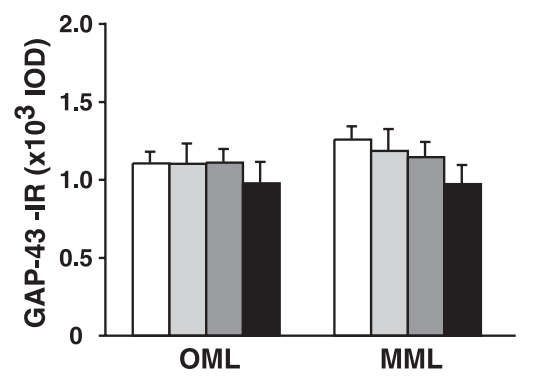

Figure 3. Genetic modulation of Fyn does not affect hAPP/A $\beta$-induced aberrant sprouting. $A$, Comparable increases in GAP-43-IR in the OML of hAPP high mice on the fyn ${ }^{+/+}$and fyn ${ }^{-1-}$ background ( $n=5-8$ mice/genotype; age, $4-5$ months). ${ }^{*} p<0.005$. B, GAP-43-IR did not correlate with hippocampal $A \beta 1-42$ levels or $A \beta 1-42 / A \beta 1-x$ ratios in $\mathrm{hAPP}_{\text {high }}$ mice on the fyn $^{+1+}$ and fyn ${ }^{-1-}$ backgrounds. C, Overexpressing Fyn did not increase GAP-43-IR levels in hAPP $_{\text {low }}$ mice ( $n=5-9$ mice/genotype; age, $6-8$ months).

(Shirazi and Wood, 1993; Kohmura et al., 1998; Lauri et al., 1999; Chavis and Westbrook, 2001; Williamson et al., 2002; Grace and Busciglio, 2003).

If $A \beta$ affects Fyn itself, Fyn might be required to mediate some of the biological effects of $A \beta$. Notably, activation of Fyn can have different consequences in different brain regions. In the hippocampus, but not in the cerebral cortex, Fyn is targeted to the NR2B subunit of the NMDA receptor by the scaffolding protein RACK1 (Yaka et al., 2003). Peptides that disrupt interactions between RACK1, NR2B, and Fyn induce phosphorylation of NR2B and potentiate NMDA receptor-mediated currents (Yaka et al., 2002). Thus, increased Fyn activity might elicit excitotoxic neuronal injury in the hippocampus but not in other regions. If $\mathrm{A} \beta$ affects targets downstream of Fyn, Fyn might act primarily to prime or amplify $\mathrm{A} \beta$-induced pathogenic cascades. These possibilities are not mutually exclusive and provide a framework of testable hypotheses.

In conclusion, our study demonstrates an important role of Fyn in hAPP/A $\beta$-dependent synaptic deficits and premature death. It implies that pharmacological modulation of Fyn or related signaling pathways might be of therapeutic benefit in $\mathrm{AD}$.

\section{References}

Arendt T (2001) Disturbance of neuronal plasticity is a critical pathogenetic event in Alzheimer's disease. Int J Dev Neurosci 19:231-245.

Benowitz LI, Perrone-Bizzozero NI (1991) The expression of GAP-43 in relation to neuronal growth and plasticity: when, where, how, and why? Prog Brain Res 89:69-87.

Bi X, Gall CM, Zhou J, Lynch G (2002) Uptake and pathogenic effects of amyloid beta peptide 1-42 are enhanced by integrin antagonists and blocked by NMDA receptor antagonists. Neuroscience 112:827-840.

Bronfman FC, Moechars D, Van Leuven F (2000) Acetylcholinesterasepositive fiber deafferentation and cell shrinkage in the septohippocampal pathway of aged amyloid precursor protein london mutant transgenic mice. Neurobiol Dis 7:152-168.

Buttini M, Orth M, Bellosta S, Akeefe H, Pitas RE, Wyss-Coray T, Mucke L, Mahley RW (1999) Expression of human apolipoprotein E3 or E4 in the brains of $A p o e^{-1-}$ mice: isoform-specific effects on neurodegeneration. J Neurosci 19:4867-4880.

Buttini M, Yu G-Q, Shockley K, Huang Y, Jones B, Masliah E, Mallory M, Yeo T, Longo FM, Mucke L (2002) Modulation of Alzheimer-like synaptic and cholinergic deficits in transgenic mice by human apolipoprotein $\mathrm{E}$ depends on isoform, aging, and overexpression of amyloid $\beta$ peptides but not on plaque formation. J Neurosci 22:10539-10548.

Carlson GA, Borchelt DR, Dake A, Turner S, Danielson V, Coffin JD, Eckman C, Meiners J, Nilsen SP, Younkin SG, Hsiao KK (1997) Genetic modification of the phenotypes produced by amyloid precursor protein overexpression in transgenic mice. Hum Mol Genet 6:1951-1959.

Caughey B, Lansbury Jr PT (2003) Protofibrils, pores, fibrils, and neurodegeneration: separating the responsible protein aggregates from the innocent bystanders. Annu Rev Neurosci 26:267-298.

Chavis P, Westbrook G (2001) Integrins mediate functional pre- and postsynaptic maturation at a hippocampal synapse. Nature 411:317-321.

DeKosky ST, Scheff SW (1990) Synapse loss in frontal cortex biopsies in Alzheimer's disease: correlation with cognitive severity. Ann Neurol 27:457-464.

Dineley KT, Westerman M, Bui D, Bell K, Ashe KH, Sweatt JD (2001) $\beta$-Amyloid activates the mitogen-activated protein kinase cascade via hippocampal $\alpha 7$ nicotinic acetylcholine receptors: in vitro and in vivo mechanisms related to Alzheimer's disease. J Neurosci 21:4125-4133.

Geddes JW, Monaghan DT, Cotman CW, Lott IT, Kim RC, Chui HC (1985) Plasticity of hippocampal circuitry in Alzheimer's disease. Science 230:1179-1181.

Grace EA, Busciglio J (2003) Aberrant activation of focal adhesion proteins mediates fibrillar amyloid $\beta$-induced neuronal dystrophy. J Neurosci 23:493-502.

Grant SGN, O’Dell TJ, Karl KA, Stein PL, Soriano P, Kandel ER (1992) Impaired long-term potentiation, spatial learning, and hippocampal development in fyn mutant mice. Science 258:1903-1910.

Holcomb LA, Gordon MN, Jantzen P, Hsiao K, Duff K, Morgan D (1999) Behavioral changes in transgenic mice expressing both amyloid precursor protein and presenilin-1 mutations: lack of association with amyloid deposits. Behav Genet 29:177-185.

Hsia A, Masliah E, McConlogue L, Yu G, Tatsuno G, Hu K, Kholodenko D, Malenka RC, Nicoll RA, Mucke L (1999) Plaque-independent disruption of neural circuits in Alzheimer's disease mouse models. Proc Natl Acad Sci USA 96:3228-3233.

Hsiao KK, Borchelt DR, Olson K, Johannsdottir R, Kitt C, Yunis W, Xu S, Eckman C, Younkin S, Price D, Iadecola C, Clark HB, Carlson G (1995) Age-related CNS disorder and early death in transgenic FVB/N mice overexpressing Alzheimer amyloid precursor proteins. Neuron 15:1203-1218.

Jaffar S, Counts SC, Ma SY, Dadko E, Gordon MN, Morgan D, Mufson EJ (2001) Neuropathology of mice carrying mutant $\mathrm{APP}_{\text {swe }}$ and/or 
PS1 $1_{\mathrm{m} 146 \mathrm{~L}}$ transgenes: alterations in the $\mathrm{p} 75^{\mathrm{NTR}}$ cholinergic basal forebrain septohippocampal pathway. Exp Neurol 170:227-243.

Johnson-Wood K, Lee M, Motter R, Hu K, Gordon G, Barbour R, Khan K, Gordon M, Tan H, Games D, Lieberburg I, Schenk D, Seubert P, McConlogue L (1997) Amyloid precursor protein processing and $\mathrm{A} \beta_{42}$ deposition in a transgenic mouse model of Alzheimer disease. Proc Natl Acad Sci USA 94:1550-1555.

Kamenetz F, Tomita T, Hsieh H, Seabrook G, Borchelt D, Iwatsubo T, Sisodia S, Malinow R (2003) APP processing and synaptic function. Neuron 37:925-937.

Klein WL (2000) A $\beta$ toxicity in Alzheimer's disease. In: Molecular mechanisms of neurodegenerative diseases (Chesselet M-F, ed), pp 1-49. Totowa, NJ: Humana.

Kohmura N, Senzaki K, Hamada S, Kai N, Yasuda R, Watanabe M, Ishii H, Yasuda M, Mishina M, Yagi T (1998) Diversity revealed by a novel family of cadherins expressed in neurons at a synaptic complex. Neuron 20:1137-1151.

Kojima N, Wang J, Mansuy IM, Grant SGN, Mayford M, Kandel ER (1997) Rescuing impairment of long-term potentiation in fyn-deficient mice by introducing Fyn transgene. Proc Natl Acad Sci USA 94:4761-4765.

Kojima N, Ishibashi H, Obata K, Kandel ER (1998) Higher seizure susceptibility and enhanced tyrosine phosphorylation on $N$-methyl-D-aspartate receptor subunit 2B in fyn transgenic mice. Learn Mem 5:429-445.

Lambert MP, Barlow AK, Chromy BA, Edwards C, Freed R, Liosatos M, Morgan TE, Rozovsky I, Trommer B, Viola KL, Wals P, Zhang C, Finch CE, Krafft GA, Klein WL (1998) Diffusible, nonfibrillar ligands derived from $\mathrm{A} \beta_{1-42}$ are potent central nervous system neurotoxins. Proc Natl Acad Sci USA 95:6448-6453.

Lauri SE, Kaukinen S, Kinnunen T, Ylinen A, Imai S, Kaila K, Taira T, Rauvala H (1999) Regulatory role and molecular interactions of a cell-surface heparan sulfate proteoglycan $(N$-syndecan) in hippocampal long-term potentiation. J Neurosci 19:1226-1235.

Masliah E, Mallory M, Hansen L, Alford M, Albright T, DeTeresa R, Terry R, Baudier J, Saitoh T (1991) Patterns of aberrant sprouting in Alzheimer's disease. Neuron 6:729-739.

Masliah E, Ellisman M, Carragher B, Mallory M, Young S, Hansen L, DeTeresa R, Terry RD (1992) Three-dimensional analysis of the relationship between synaptic pathology and neuropil threads in Alzheimer disease. J Neuropathol Exp Neurol 51:404-414.

Mucke L, Masliah E, Johnson WB, Ruppe MD, Alford M, Rockenstein EM, Forss-Petter S, Pietropaolo M, Mallory M, Abraham CR (1994) Synaptotrophic effects of human amyloid $\beta$ protein precursor in the cortex of transgenic mice. Brain Res 666:151-167.

Mucke L, Masliah E, Yu G-Q, Mallory M, Rockenstein EM, Tatsuno G, Hu K, Kholodenko D, Johnson-Wood K, McConlogue L (2000) High-level neuronal expression of $\mathrm{A} \beta_{1-42}$ in wild-type human amyloid protein precursor transgenic mice: synaptotoxicity without plaque formation. J Neurosci 20:4050-4058.
Palop JJ, Jones B, Kekonius L, Chin J, Yu G-Q, Raber J, Masliah E, Mucke L (2003) Neuronal depletion of calcium-dependent proteins in the dentate gyrus is tightly linked to Alzheimer's disease-related cognitive deficits. Proc Natl Acad Sci USA 100:9572-9577.

Phinney AL, Deller T, Stalder M, Calhoun ME, Frotscher M, Sommer B, Staufenbiel M, Jucker M (1999) Cerebral amyloid induces aberrant axonal sprouting and ectopic terminal formation in amyloid precursor protein transgenic mice. J Neurosci 19:8552-8559.

Raber J, Wong D, Yu G-Q, Buttini M, Mahley RW, Pitas RE, Mucke L (2000) Alzheimer's disease: apolipoprotein $\mathrm{E}$ and cognitive performance. Nature 404:352-354.

Rockenstein EM, McConlogue L, Tan H, Gordon M, Power M, Masliah E, Mucke L (1995) Levels and alternative splicing of amyloid $\beta$ protein precursor (APP) transcripts in brains of transgenic mice and humans with Alzheimer's disease. J Biol Chem 270:28257-28267.

Sabo S, Lambert MP, Kessey K, Wade W, Krafft G, Klein WL (1995) Interaction of $\beta$-amyloid peptides with integrins in a human nerve cell line. Neurosci Lett 184:25-28.

Selkoe DJ, Schenk D (2003) Alzheimer's disease: molecular understanding predicts amyloid-based therapeutics. Annu Rev Pharmacol Toxicol 43:545-584.

Shirazi SK, Wood JG (1993) The protein tyrosine kinase, fyn, in Alzheimer's disease pathology. NeuroReport 4:435-437.

Small DH, Mok SS, Bornstein JC (2001) Alzheimer's disease and A $\beta$ toxicity: from top to bottom. Nat Rev Neurosci 595:595-598.

Terry RD, Masliah E, Hansen LA (1999) The neuropathology of Alzheimer disease and the structural basis of its cognitive alterations. In: Alzheimer disease, Ed 2 (Terry RD, Katzman R, Bick KL, Sisodia SS, eds), pp 187206. Philadelphia: Lippincott Williams and Wilkins.

Westerman MA, Cooper-Blacketer D, Mariash A, Kotilinek L, Kawarabayashi T, Younkin LH, Carlson GA, Younkin SG, Ashe KH (2002) The relationship between $\mathrm{A} \beta$ and memory in the Tg2576 mouse model of Alzheimer's disease. J Neurosci 22:1858-1867.

Williamson R, Scales T, Clark BR, Gibb G, Reynolds CH, Kellie S, Bird IN, Varndell IM, Sheppard PW, Everall I, Anderton BH (2002) Rapid tyrosine phosphorylation of neuronal proteins including tau and focal adhesion kinase in response to amyloid- $\beta$ peptide exposure: involvement of Src family protein kinases. J Neurosci 22:10-20.

Yaar M, Zhai S, Pilch PF, Doyle SM, Eisenhauer PB, Fine RE, Gilchrest BA (1997) Binding of beta-amyloid to the p75 neurotrophin receptor induces apoptosis—a possible mechanism for Alzheimer's disease. J Clin Invest 100:2333-2340.

Yaka R, Thornton C, Vagts AJ, Phamluong K, Bonci A, Ron D (2002) NMDA receptor function is regulated by the inhibitory scaffolding protein, RACK1. Proc Natl Acad Sci USA 99:5710-5715.

Yaka R, Phamluong K, Ron D (2003) Scaffolding of Fyn kinase to the NMDA receptor determines brain region sensitivity to ethanol. J Neurosci 23:3623-3632. 